\title{
Database Temperate Deciduous Forests of the Elbe-Weser Region
}

\author{
Monika Wulf
}

\begin{abstract}
For her own PhD, Monika Wulf investigated 415 plots (vegetation relevés) in 77 mixed broadleaf forests from 1986 to 1989. The 415 plots (100-400 $\left.\mathrm{m}^{2}\right)$ represent alder forests on wet soils, ash dominated stands on wet, moist and moderately moist sites, oak-hornbeam forests on fresh soils, and beech dominated forests on moderately fresh soils. In each plot the abundance of all vascular plants per stratum (first and second tree layer, shrub and herb layer) was estimated using the scale of Barkman. Bryophytes were noted as presence/absence data. The latitude and the longitude of maps at scale 1:25,000 (exact coordinates with an average deviance of 10$20 \mathrm{~m}$ ) were determined for each plot. Additionally, locations of the plots were drawn on maps at scale 1:10,000 and sketches with positions of the main tree and shrub species within the plot and at the plot boundaries were drawn. In a selected number of 127 plots from 30 forests soil samples were taken at three different horizons $(0-5 \mathrm{~cm}, 5-10 \mathrm{~cm}$, and 10-20 cm). At each plot 10 sub-samples were taken with a soil auger of $5 \mathrm{~cm}$ diameter, and were mixed separately for the three horizons to one sample. The soil samples were used to estimate the $\mathrm{pH}$ using a $\mathrm{CaCl}_{2}$-standard solution, and to determine the amount of the plant available cations $\mathrm{Ca}, \mathrm{K}, \mathrm{Mg}$ and $\mathrm{P}$ using an ammonium-acetate-solution. Determination of the cation concentrations were made with a spectral photometer and an atomabsorptions-spectrometer (AAS), respectively. In 2007 and 2008 nearly all plots (380 of 415) have been exactly relocated and their positions were fixed by means of GPS. They can, together with the manual sketches, be easily relocated in the future. The purpose for relocation was to detect changes in the herb layer after 20 years. To test hypothesis of biotic homogenization at the regional level a subset of 175 independent plots were investigated by Tobias Naaf in 2008 and 2009 to carry out his PhD. These studies were founded by the German Research Foundation (DFG). This report describes the available content in the Database Temperate Deciduous Forests of the Elbe-Weser Region (GIVD ID EU-DE-005).
\end{abstract}

Keywords: abundance; Chrysosplenio oppositifolii-Alnetum glutinosae; Crepido-Fraxinetum; Melico-Fagetum; pH; plant available cation; soil profile; Stellario-Carpinetum stachyetosum.

\section{GIVD Database ID: EU-DE-005 \\ Database Temperate Deciduous Forests of the Elbe-Weser Region}

Last update: 2011-07-06

Scope: Description of deciduous forest communities and analysis of distribution patterns of selected herbaceous plant species in the Weser-Elberegion (PhD of Monika Wulf)

Status: finished

Period: $1986-1989$

Database manager(s): Monika Wulf (mwulf@zalf.de)

Owner: Prof. Dr. Monika Wulf, Leibniz-ZALF, Institute of Land Use Systems

Web address: http://www.zalf.de/home_zalf/institute/lse/lse/mitarbeiter/wulf/general.htm

Availability: according to a specific agreement Online upload: no

Online search: no

Database format(s): Excel

Export format(s): [NA]

Publication: Wulf, M. 1992. Vegetationskundliche und ökologische Untersuchungen zum Vorkommen gefährdeter Pflanzenarten in Feuchtwäldern Nordwestdeutschlands. Diss. Bot. 185: 1-246.

Plot type(s): normal plots

Non-overlapping plots: 415

Plot-size range: $100-400 \mathrm{~m}^{2}$

Total plot observations: 415

Estimate of existing plots: 415

Completeness: $100 \%$

Countries: DE: $100.0 \%$

Forest: [NA] - Non-forest: [NA]

Guilds: all vascular plants: 100\%; bryophytes (terricolous or aquatic): $100 \%$

Environmental data: surface cover other than plants (open soil, litter, bare rock etc.): $95 \%$; soil pH: $31 \%$

Performance measure(s): cover: $100 \%$

Geographic localisation: GPS coordinates (precision $25 \mathrm{~m}$ or less): $92 \%$; point coordinates less precise than GPS, up to $1 \mathrm{~km}: 8 \%$

Sampling periods: $1980-1989: 100.0 \%$

Information as of 2012-07-12; further details and future updates available from http://www.givd.info/ID/EU-DE-005

Monika Wulf (mwulf@zalf.de)

Land Use Systems, Centre for Agricultural Landscape Research (Leibniz-ZALF), Eberswalder Str. 84, 15374 Müncheberg, GERMANY 